\title{
NEW RECORD OF BATASIO SHARAVATIENSIS BHATT AND JAYARAM FROM TUNGA RIVER, KARNATAKA
}

\section{Arunachalam ${ }^{1}$ and M. Muralidharan ${ }^{2}$}

1,2 Sri Paramakalyani Centre for Environmental Sciences, Manonmaniam Sundaranar University, Alwarkurichi, Tamil Nadu 627412, India Email: ${ }^{1}$ arunacm@gmail.com

plus web supplement of 1 page

\section{Abstract}

Batasio sharavatiensis Bhatt \& Jayaram, 2004 was described from river Shravathi and its distribution was confined to Shravathi basin. The present study reports the occurrence of this species in Thunga river basin, showing the extension in range of its distribution further south from type locality to another river basin.

\section{KeYworDs}

Batasio sharavatiensis, new record, Sharavathi river, Tunga river basin

Bagrid cat fishes of the genus Batasio Blyth, 1860 are species with small head and laterally compressed body that generally inhabit hillstreams with medium to high water current. They are found throughout South and South East Asia. They are characterized by head with large sensory pores, a pair of prominent posterior processes on the anterior part of the vomer, transversely elongated, bar like entopterygoid and by the metapterygoid in close contact with the quadrate (Mo, 1991). Recent review by $\mathrm{Ng} \&$ Edds (2004) recognized 12 valid species: B. batasio (Hamilton-Buchanan, 1822), B. tengana (Hamilton-Buchanan, 1822), B. affinis Blyth, 1860, B. dayi (Vinciguerra, 1890), B. merianiensis, (Chaudhuri, 1931), B. havmolleri (Smith, 1931), B. travancoria (Hora \& Law, 1941), B. pakistanicus (Mirza \& Jan, 1989), B. tigrinus ( $\mathrm{Ng} \&$ Kottelat, 2001), B. elongates (Ng, 2004), B. sharavatiensis (Bhatt \& Jayaram, 2004) and B. macronotus ( Ng \& Edds, 2004). Three new species were described last year, B. fasciolatus $\mathrm{Ng}$ (2006), B. spilurus $\mathrm{Ng}$ (2006) and B. niger Vishwanath \& Darshan (2006), making the current number of valid Batasio species 15.

Among these the identity of B. tengana has long been under confusion, as it had many similar species with wide range of morphometric variations included under synonymy. The reason as conceived by $\mathrm{Ng}$ (2006) is that the type material of B. tengana had not been properly examined by any worker which has lead to indiscriminate synonymy. It was after the detailed study (Ng \& Kottelat, 2001) three species viz. B. affinis, Blyth, B. dayi Vinciguerra, and B. havmolleri (Smith) have been resurrected and a new species B. tigrinus ( $\mathrm{Ng} \&$ Kottelat, 2001) was described. Even most recently a new species, B. fasciolatus $(\mathrm{Ng}, 2006)$ has been described from material previously identified as B. tengana from Brahmaputra drainage. With its inclusion the Indian subcontinent represents 6 species B. batasio, B. tengana, B. fasciolatus, B. spilurus all occurring in north and northeastern India and B. travancoria and B. sharavatiensis from peninsular India. B. sharavatiensis (Bhatt \& Jayaram, 2004) was described from Sharavati river in Uttara Kannada district of Karnataka state, its distribution was restricted to the Sharavati river and its tributaries.
During a recent ichthyological survey in streams of Western Ghats a bagrid catfish was collected, which was later identified as B. sharavatiensis. There has been no report of this species from habitats other than the type locality and the river basin hence the present study reports the occurrence in Vimalanathi, one of the main streams of river Tunga which extending the range in distribution of the species to Tunga river basin.

\section{MATERIALS AND METHODS}

Fishes were collected using cast nets. Specimens were preserved in 10\% formalin and kept in the Manonmanium Sundaranar University Museum of Natural History (MSUMNH), Alwarkurichi. All morphometric measurements were made in a standard fashion using digital calipers recorded to $0.1 \mathrm{~mm}$. Methods used for counts and measurements follow those of $\mathrm{Ng} \&$ Kottelat (2001). Comparison materials were from registered collection of ZSI, Zoological Survey of India, Kolkata and ZSI/SRS, Southern Regional Station, Chennai.

\section{BATASIO SHARAVATIENSIS Bhatt \& Jayaram}

(Image $1^{\mathrm{w}}$ )

Batasio sharavatiensis Bhatt \& Jayaram 2004, Zoos' Print Journal, (type locality: River Sharavati at Joginmatha, Karnataka state).

\section{Material examined}

1 ex., 22.ii.2002, Vimalanathi at Munsar, tributary of River Thunga, inside Khudremukh National Park, Udipi district, Karnataka state, $91.3 \mathrm{~mm} \mathrm{SL}$, coll. Arunachalam \& team, MSUMNH 55.

\section{Diagnosis}

Batasio sharavatiensis is diagnosed by its plain colourless body devoid of bars, bands or stripes except for the humeral spot on the shoulder and the long adipose dorsal fin almost confluent with the caudal separated by a narrow notch.

\section{Description}

Morphometric measurements are given in Table 1. Body short with rounded abdomen, deeper at dorsal region and compressed posteriorly. Dorsal profile rising evenly and gently from tip of snout to dorsal fin origin. Posterior part of body gradually sloping towards caudal base. Ventral region with a curved slope after anal fin base and flat to the caudal peduncle.

${ }^{\mathrm{w}}$ see Image $1^{\mathrm{w}}$ in the web supplement at www.zoosprint.org

Manuscript 1586; @ ZOO; Date of publication 21 April 2007 Received 06 July 2006; Finally accepted 10 April 2007 
Table 1. Comparison of morphometric characters with Batasio sharavatiensis type specimens

\begin{tabular}{|c|c|c|c|c|}
\hline & \multirow{2}{*}{$\begin{array}{l}\text { Morphometric } \\
\text { Measurements }\end{array}$} & \multirow{2}{*}{$\begin{array}{l}\text { Vimalanathi } \\
\text { at Munsar } \\
n=1\end{array}$} & \multicolumn{2}{|c|}{ B. sharavatiensis } \\
\hline & & & $\begin{array}{l}\text { Holotype } \\
\text { ZSI F. } 6419\end{array}$ & $\begin{array}{l}\text { Paratype } \\
\text { ZSI F. } 6420\end{array}$ \\
\hline 1 & Standard Length & 91.3 & 99.0 & 104.0 \\
\hline 2 & Total length & 107.3 & 118.14 & 125.01 \\
\hline 3 & Head length & 27.60 & 27.07 & 27.40 \\
\hline 4 & Body depth & 19.50 & 18.79 & 17.50 \\
\hline 5 & Pre dorsal distance & 39.43 & 39.6 & 40.0 \\
\hline 6 & Pre pectoral distance & 25.63 & 24.6 & 26.06 \\
\hline 7 & Pre anal distance & 64.8 & 65.1 & 66.6 \\
\hline 8 & Pre pelvic length & 48.41 & 48.79 & 49.04 \\
\hline 9 & Dorsal fin length & 17.52 & 17.3 & 20.87 \\
\hline 10 & Dorsal spine length & 11.72 & 9.60 & - \\
\hline 11 & Pelvic fin length & 13.25 & 13.23 & 14.13 \\
\hline 12 & Pectoral fin length & 14.57 & 14.24 & 15.9 \\
\hline 13 & Pectoral spine length & 12.16 & 12.42 & - \\
\hline 14 & Anal fin length & 11.83 & 8.69 & 8.85 \\
\hline 15 & Caudal fin length & 19.5 & 19.29 & 18.75 \\
\hline 16 & Basal width of dorsal fin & 12.38 & 13.03 & 13.56 \\
\hline 17 & Basal width of pelvic fin & 3.07 & 2.83 & 2.88 \\
\hline 18 & Basal width of pectoral fin & 3.50 & 3.33 & 3.85 \\
\hline 19 & Basal width of anal fin & 18.62 & 19.39 & 21.15 \\
\hline 20 & Peduncle length & 14.79 & 16.87 & 16.0 \\
\hline 21 & Peduncle depth & 7.01 & 6.87 & 6.05 \\
\hline \multirow[t]{2}{*}{22} & Adipose fin base & 40.53 & 48.89 & 49.33 \\
\hline & $\% \mathrm{HL}$ & & & \\
\hline 23 & Head depth & 55.56 & 58.58 & 56.49 \\
\hline 24 & Head width & 58.3 & 53.36 & 54.74 \\
\hline 25 & Snout length & 40.48 & 37.31 & 35.4 \\
\hline 26 & Eye diameter & 15.08 & 15.3 & 15.4 \\
\hline 27 & Inter orbital width & 25.39 & 17.91 & 18.25 \\
\hline 28 & Nasal barbel & 14.29 & - & - \\
\hline 29 & Maxillary barbel & 29.37 & 29.4 & - \\
\hline 30 & Mandibular barbel inner & 11.90 & 10.04 & - \\
\hline 31 & Mandibular barbel outer & 20.63 & 20.52 & - \\
\hline
\end{tabular}

Head small, smooth and depressed. Snout rather conical with rounded tip. Sensory pores prominent. Presence of pores on head is a generic character, it has been discussed here to show the pattern. Five large pores distinct on ventral part of head, the outermost rounded others oval, found immediately behind lower lip. Two rows of pores (6 in each) in the space between and below the angle of mouth and opercle. Pores also found on dorsal part of head up to occiput i.e. prenasal region, interorbital space and below eyes along the border of gill cover. Gill rakers 10 in total on the first gill arch, two on the epibranchial and eight on the ceratobranchial. Six small tubercle like projections in the lower arm prior to the commencement of the distinguishable gill rakers.

Eyes small, dorso-lateral, placed in the anterior half of middle of head, not visible from ventral side. Mouth small, inferior and crescent shaped, lips fleshy and fimbriated. Teeth villiform in broad continuous bands in jaws. Upper jaw with broader band rectangular in shape followed by band in the palate after a narrow interspace. Lower jaw teeth crescent shaped continuous with teeth on palate. Jaws subequal. A deep groove at angle of mouth on either side. Median region between lower lip and ventral notch on head fimbriated.

Barbels four pairs, all shorter than head, fine and thread like, not fleshy. Nasal barbel extending up to anterior margin of eye. Rostral barbel extending to little before middle of eye. Mandibular barbels, outer pair reaching the deep groove on the ventral part where gill membranes are notched. Inner mandibular barbel extends to base of pectoral fin. Occipital process short separated by a considerable distance from basal bone of dorsal fin. Median longitudinal groove not distinct, but with the presence of smooth skin in the region. Caudal fin base rounded narrow at peduncle, with the presence of adipose fin extending to caudal fin. Vent located in midline enclosed by the pelvic fins, about midway in the length of the pelvic fin. A long slender genital papilla found extending to base of anal fin, feature that is probably present in males. Adipose fin with convex margin through out its length its posterior end confluences with the caudal fin.

Dorsal fin with one smooth spine of moderate strength and seven branched rays. Compressed fin reaches adipose fin origin, free margin convex. Pelvic fin with one branched and five branched rays not extending up to anal fin, origin behind the dorsal fin insertion above. Pectoral fin with nine rays, eight branched rays, unbranched ray as strong spine, with 14 serrations in the inner edge, curved inside. Pectoral fin when gently adpressed along body reaches third branched ray of dorsal fin above. Caudal fin rounded with $17-18$ rays $8+8$ branched rays with two principal rays one each on outer edge of caudal fin lobes. Anal fin with four simple and 13 branched rays and the distal margin convex.

Procurrent rays (counted upto the rays easily visible) 11 on the dorsal side and 10 on the ventral side.

\section{Colouration}

In life gray, darker in the dorsal region, paler towards the ventral side. Formalin preserved specimens: dorsal part of body darker, head region up to occiput, adipose fin darker. Body plain without any bars or bands expect for the elongated black spot at the shoulder.

\section{Comparative materials}

Holotype: ZSI/SRS F 6419, 99.0mm SL, 8.iii.1998, Sharavati river at Joginmatha, $\left(14^{\circ} 4^{\prime} \mathrm{N} \& 74^{\circ} 49^{\prime} \mathrm{E}\right)$ Uttara Kannada district, Karnataka, coll. Anuradha Bhatt.

Paratype: ZSI/SRS F 6420, 104.0mm SL, same as above.

Topotypes: 2 ex., 20.ii.2003, Yennehole, tributary of Sharavati river $\left(13^{\circ} 57^{\prime} 42.6^{\prime \prime} \mathrm{N} \& 74^{\circ} 43^{\prime} 30.9^{\prime \prime} \mathrm{E}\right)$, Karnataka, 76.7-101.9mm SL, coll. Arunachalam \& team, MSUMNH 56.

\section{Site description}

Vimalanathi is a small stream that confluences with Tunga river and the study site was at Munsar located inside Khudremukh National Park (Fig. 1), one of the important protected areas in Karnataka.

\section{Comparison of species}

The specimen collected in the present survey from Vimalanathi is similar in meristic and morphometric features and agrees with almost all the characters found in registered type specimens except few body characters like the dorsal spine length, anal fin length, adipose fin length and interorbital distance among head characters (Table 1). The gill raker count was same as found in type specimens, but with six evenly spaced small papilla seen prior to the distinct gill rakers in the lower arm. Few measurements of type, related to barbels and 


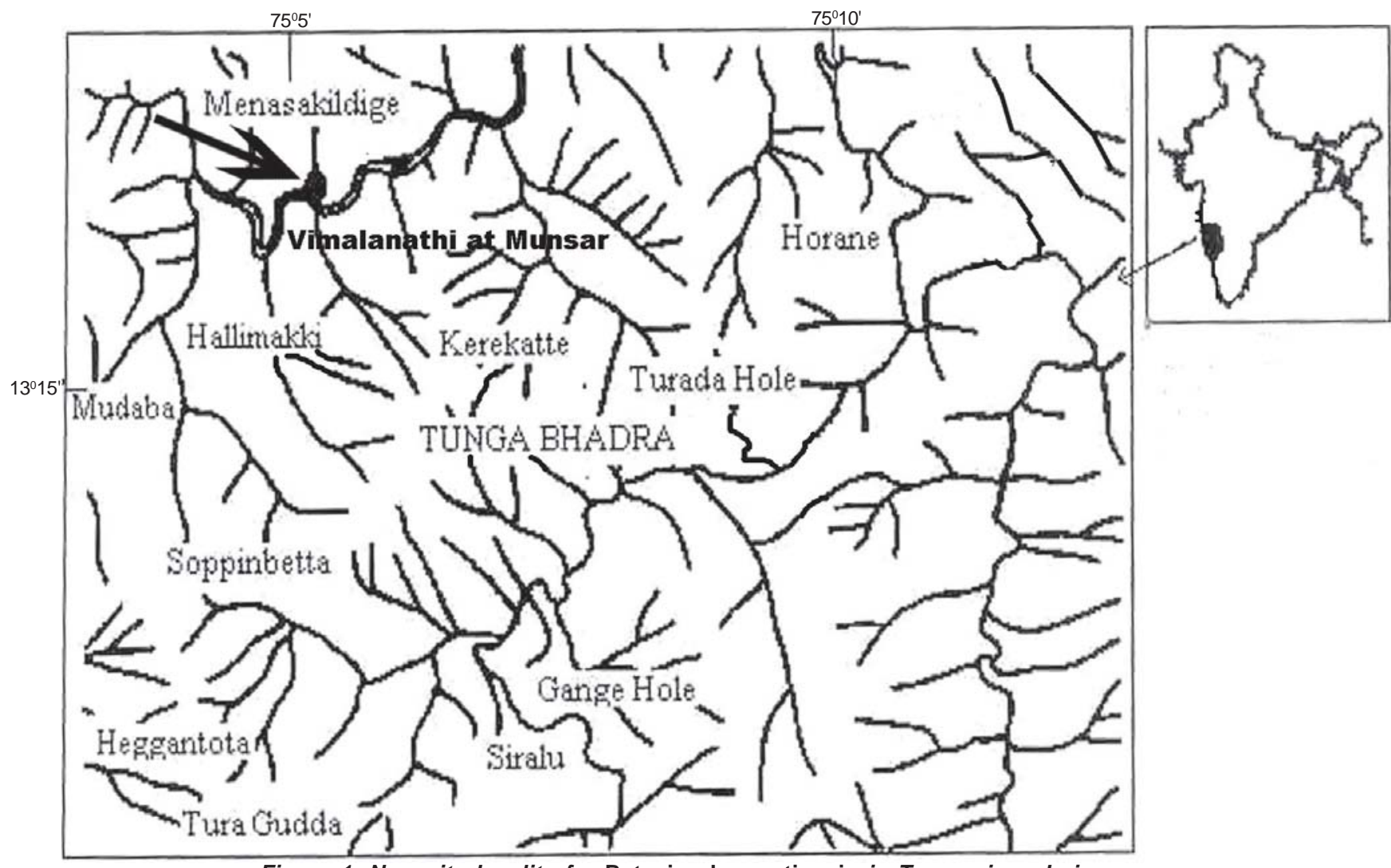

Figure 1. New site locality for Batasio sharavatiensis in Tunga river drainage

spines have been left blank without values in (Table 1) in order to avoid wide variation among the types, since the barbels in that specimen had broken tips.

\section{Discussion}

All the species of genus Batasio, other than B. sharavatiensis are characterized by the presence of bars, bands, or spots and are not plain without such colourations (Bhatt \& Jayaram, 2004). The humeral spot in shoulder region is the only marked colouration in the plain body, similar spot has also been noted in B. pakistanicus, as mentioned by $\mathrm{Ng}$ (2006) but we have not examined those specimens. The two specimens we had collected during our previous survey from Yennahole, a tributary of Sharavati river were also examined, the anal fin had 3-4 simple and 15-16 branched (vs. 3 simple \& 14-15 branched) and the caudal fin rays $8+9$ (vs. $8+8$ ) including the simple principal ray. No other remarkable variation was noted in these specimens.

\section{REFERENCES}

Bhatt, A. \& K.C. Jayaram (2004). A new species of the genus Batasio Blyth (Siluriformes: Bagridae) from Shravathi river, Uttar Kannada, Karnataka. Zoos' Print Journal 19(2): 1339-1342.
Mo, T.P. (1991). Anatomy and systematics of bagridae (Teleostei) and Siluroid phylogeny. Theses Zoologicae 17: 1-216.

Ng, H.H. (2006). The identity of Batasio tengana (Hamilton, 1822), with the description of two new species of Batasio from north-eastern India (Telestei: Bagridae). Journal of Fish Biology 68(A): 101-118.

Ng, H.H. \& D.R. Edds (2004). Batasio macronotus, a new species of bagrid catfish from Nepal (Teleostei: Bagridae). Ichthyological Explorations of Freshwaters 15: 295-300.

Ng, H.H. \& M. Kottelat (2001). A review of the genus Batasio (Teleostei: Bagridae) in Indochina, with the description of B. tigrinus sp. n. from Thailand. Revue Suisse de Zoologie 108: 495- 511 .

Vishwanath, W. \& A. Darshan (2006). A new species of the genus Batasio Blyth (Teleostei: Bagridae) from Manipur. Zoos' Print Journal 21(2): 2160-2163.

\section{Acknowledgements}

MA is grateful for the financial assistance from NATP under the Mission Mode Programme of "Germplasm Inventory Evaluation and Gene Banking of Freshwater Fishes" (Sanction No. 27 (281/98/NATP/MM - III 18 Dt. 23.12.1999). We also thank Dr. D. Kapoor, Mission Leader and Director and Dr. S.P. Singh, Principal Investigator, Lead Centre, National Bureau of Fish Genetic Resources, Lucknow for the lead role in this programme.

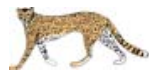

